\title{
3
}

Forum: Life Writing and American Studies

the realist film. Rather than opening a window directly onto the past, it opens a window onto a different way of thinking about the past." Robert A. Rosenstone, "The Historical Film as Real History," Film-Historia 5, no. 1 (1995), http://revistes.ub.edu/index.php/filmhistoria/article/view/12244/14998.

12 Smith and Watson, Reading Autobiography, 19.

13 John Corner, "Performing the Real: Documentary Diversions," Television and New Media 3, no. 3 (2002): 257, https://doi.org/10.1177/152747640200300302.

14 Lane, Autobiographical Documentary, 192.

\section{Online Life Writing}

Silvia Schultermandl, University of Graz DOI: 10.47060/jaaas.viii.76

The advent of Facebook in 2004, Twitter in 2006, Tumblr in 2007, Instagram and Pinterest in 2010, and Snapchat and Google+ in 2011 facilitated the emergence of "everyday" autobiographies out of keeping with memoir practices of the past.' These "quick media" enable constant, instantaneous, and seemingly organic expressions of everyday lives. ${ }^{2}$ To read quick media as "autobiographical acts" allows us to analyze how people mobilize online media as representations of their lives and the lives of others. ${ }^{3}$ They do so through a wide range of topics including YouTube testimonials posted by asylum seekers and the life-style-oriented content on Pinterest. ${ }^{4}$ To be sure, the political content of these different quick-media life writing forms varies greatly. Nevertheless, in line with the feminist credo that the personal is political, these expressions of selfhood are indicative of specific societal and political contexts and thus contribute to the memoir boom long noticed on the literary market. ${ }^{5}$

Through this collapse of the boundaries between offline and online lives it becomes clear that quick media are sources of empowerment and vulnerability at the same time: notions of a democratic (easily accessible and affordable) usage coalesce with issues of user security and big data mining, on the one hand, and new social division along the infamous "digital divide" between internet-savvy users and those who lack the resources to participate in this form of online communication culture, ${ }^{6}$ on the other. And while in media studies the skepticism toward the quality of cyber-relationships produces interesting observations about the social use of social media, the field of life writing studies has witnessed a proliferation of new terminology which addresses the multi-medial and multi-modal shape given to online lives. For instance, the concept of "autobiographics" describes the practice of uploading visual content; similarly, the concept of "auto assemblages" references the layers of text generally featured on quick media that replace understanding of the verbal mediation of life narratives. ${ }^{8}$ Likewise, practices such as "auto/curating" point toward a form of autobiographical self-expression composed primarily 


\section{$3 \%$}

Nassim W. Balestrini et al.

of images. ${ }^{9}$ These new concepts acknowledge the performative aspect of identity through quick media.

Quick media also have particular salience with regard to questions of kinship and community in a networked world. ${ }^{10}$ Phenomena ranging from representations of non-traditional family models and the meeting of ersatz families in thematically clustered online platforms to the use of quick media for transnational families to connect over long distances and extended periods of absence throw into relief the concomitance of technological innovation and the emergence of new concepts and practices of kinship formation: trending hashtags such as \#MeToo and \#SignedByTrump have successfully addressed systemic sexism and created spaces for agency, community building, and empowerment. Similarly, quick media push the definitions of kinship and family toward inclusive family models, gender-fluid parenting, queer kinship, and transnational kinship.

While the concern with kinship and community constitutes one particular area in which the study of quick media has generated new insights, the relational nature of online life writing branches more broadly into research areas ranging from narratology to postmodern identity theories. For instance, the concept of the self-in-relation bespeaks networked interactivity, which relies on a "many-to-many structure, with a range of participants being private in public," and it refers to ongoing debates about the prevalence of the self in online media and the relational aspect of identity in the context of family and kinship.

The notion of accessing other people's "selves" through their online writing also raises questions about the constituency of the self in the networked constellation with other "authors" and "readers" who are active on quick media." This entails reconsidering the stability of the narrating "I" and its accountability to what Philippe Lejeune termed the "autobiographical pact,"13 especially since the advent of quick media brought about new forms of online expressions of the self which are, paradoxically, not so much about the self than about the constellations which shape subjectivities. While the content is self-selected and designed to represent individual identities, the networked nature of quick media highlights the collective context rather than the singular position of the individual. Further along these lines are analyses of the strategies of affective interpellation that are particular to online life writing's interactive and intermedial nature. ${ }^{1 / 4}$

While the immanence and spontaneity afforded by quick media technologies invites assumptions about online life writing as "authentic" expression, critics have tended to emphasize the composite nature of online texts. The interaction between multiple co-authors and co-creators of a life narrative-through such acts as tagging, reposting, and liking-participates equally in the production of the text as its 


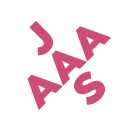

Forum: Life Writing and American Studies

author of the text. At the same time, a certain degree of authenticity resides in the rhizomatic and multi-layered representation of the dialogic, subjective, and convoluted selves performed in online spaces. ${ }^{15}$ They are cultural artifacts of networked lives that capture the communicative practices of the contemporary era.

\section{Notes}

1 Sidonie Smith and Julia Watson, eds., Getting a Life: Everyday Use of Autobiography (Minneapolis: University of Minnesota Press, 1996).

2 May Friedman and Silvia Schultermandl, "Introduction," in Click and Kin: Transnational Identity and Quick Media, ed. May Friedman and Silvia Schultermandl (Toronto: University of Toronto Press, 2016), 9.

3 Sidonie Smith and Julia Watson, Interfaces: Women, Autobiography, Images, Performance (Ann Arbor: University of Michigan Press, 2002), 4.

4 Gillian Whitlock, Postcolonial Life Narratives: Testimonial Transactions (New York: Oxford University Press, 2015); Laurie McNeill, "Digital Dioramas: Curating Life Narratives on the World Wide Web" (paper presented at the 2013 MLA Conference, Boston, MA, January 5, 2013).

5 Julie Rak, Boom! Manufacturing Memoir for the Popular Market (Waterloo, ON: Wilfrid Laurier University Press, 2013).

6 Gillian Youngs, "Cyberspace: The New Feminist Frontier?" in Women and Media: International Perspectives, ed. Karen Ross and Carolyn M. Byerly (Malden, MA: Blackwell Publishing, 2004), 185-209.

7 Sherry Turkle, Alone Together: Why We Expect More from Technology and Less from Each Other (New York: Basic Books, 2011).

8 Gillian Whitlock and Anna Poletti, "Self-Regarding Art," in "Autographics," ed. Gillian Whitlock and Anna Poletti, special issue, Biography 31, no. 1 (2008): xv, xx, https://doi. org/10.1353/bio.0.0004.

9 McNeill, "Digital Dioramas."

10 May Friedman and Silvia Schultermandl, eds. "Autobiography 2.0 and Quick Media Life Writing," special issue, Interactions: Studies in Culture and Communications 9, no. 2 (2018).

11 Laurie McNeill and John David Zuern, "Online Lives 2.0: Introduction," in "Online Lives 2.0," ed. Laurie McNeill and John David Zuern, special issue, Biography 38, no. 2 (2015):xi, https://doi.org/10.1353/bio.2015.0012.

12 Jason Breiter, Orly Lael Netzer, Julie Rak, and Lucinda Rasmussen, eds. "Auto/Biography in Transit," special issue, Biography 38, no. 1 (2015); Gillian Whitlock, "Post-ing Lives," in "(Post)Human Lives," ed. Gillian Whitlock, special issue, Biography 35, no. 1 (2012): v-xvi, https://doi.org/10.1353/bio.2012.0000.

13 Philippe Lejeune, On Autobiography, trans. Katherine Leary (Minneapolis: University of Minnesota Press, 1989), 3.

14 Anna Poletti, "Reading for Excess: Relational Autobiography, Affect and Popular Culture in Tarnation," Life Writing 9, no. 2 (2012): 157-72, https://doi.org/10.1080/14484528.2012 


\section{5}

Nassim W. Balestrini et al.

.667363; Silvia Schultermandl, "Auto-Assembling the Self on Social Networking Sites: Intermediality and Transnational Kinship in Online Academic Life Writing," in Intermediality, Life Writing, and American Studies, ed. Nassim W. Balestrini and Ina Bergmann (Berlin: de Gruyter, 2018), 191-210.

Friedman and Schultermandl, eds., "Autobiography 2.0.”

\section{Intermedial and Transnational Hip-Hop Life Writing}

Nassim W. Balestrini, University of Graz

DOI: 10.47060/jaaas.v1i1.77

The growing popularity of celebrity life writing and of memoirs which focus on the respective memoirist's specific social, professional, ethnic, or other context has also spawned a large number of autobiographical publications by persons in the music industry. The field of musical autobiography is a recent development for which a niche in life writing scholarship has only been carved out in the past decade. The growing number of autobiographical book publications as well as autobiographical self-representations in non-analog, non-printed, not primarily verbal formats raises the question as to whether specific genres of hip-hop life writing have been evolving and as to the perspectives from which scholars should discuss them.

Situating musicians' life writing in general and hip-hop life writing in particular within the larger field of life writing studies poses multiple challenges. The asymmetrical power relation between a celebrity artist and her/his writer or editor in co-authored autobiographies, for example, sits uneasily with representing the artist/star through the lens of Enlightenment-style autobiographical discourse. Such discourse implies a narrative not only of social and economic upward mobility but also of a concomitant accumulation of knowledge and insight that the reader should emulate. Nevertheless, the Enlightenment autobiographical model is often used as a means of providing "high cultural legitimacy," particularly for artists in popular music genres. ${ }^{2}$ A prominent example of a hip-hop artist's memoir that takes up this challenge of not following a traditional formula is Ahmir "Questlove" Thompson's Mo' Meta Blues (2013), which includes multiple jabs at the traditional supremacy of the co-writer or editor and at the expectations regarding the stable-self narrative established by Enlightenment autobiography. ${ }^{4}$ As I discuss elsewhere, Questlove upends the often racially informed imbalance between autobiographical subject and representatives of mainstream publication contexts through a polyvocal narrative that privileges his life narration and his (written) exchanges with Richard Nichols, the former manager of Questlove's group The Roots, on the one hand, and that gradually and humorously diminishes the role of his editor and a representative of his publisher whose email exchanges are interspersed into the main narrative. Eventually, the editor and the publisher's representative admit that Questlove 